\title{
Development of Polymerase Chain Reaction Primers Highly Specific for Xanthomonas albilineans, the Causal Bacterium of Sugarcane Leaf Scald Disease
}

\author{
Y.-B. Pan, Research Geneticist, M. P. Grisham, Research Plant Pathologist, D. M. Burner, Research Geneticist, \\ B. L. Legendre, Supervisory Research Agronomist, and Q. Wei, Research Associate, USDA-ARS, Southern Re- \\ gional Research Center, Sugarcane Research Unit, 5883 USDA Road, Houma, LA 70360
}

\begin{abstract}
Pan, Y.-B., Grisham, M. P., Burner, D. M., Legendre, B. L., and Wei, Q. 1999. Development of polymerase chain reaction primers highly specific for Xanthomonas albilineans, the causal bacterium of sugarcane leaf scald disease. Plant Dis. 83:218-222.

New primers were developed that greatly improved the specificity of the polymerase chain reaction (PCR) protocol for Xanthomonas albilineans, the causal agent of sugarcane leaf scald disease. Length-polymorphic PCR products, amplified under the current PCR protocol from the 16S-23S ribosomal DNA intergenic transcribed spacers (ITS) of $X$. albilineans and three unidentified sugarcane saprophytic bacterial species, were cloned and sequenced. Fourteen other nonredundant ITS sequences retrieved from the database were highly homologous to the sequence of $X$. albilineans. Two $X$. albilineans-specific PCR primers, namely, PGBL1 (5' CTT TGG GTC TGT AGC TCA GG) and PGBL2 (5' GCC TCA AGG TCA TAT TCA GC), were designed based on a multiple sequence alignment among these 18 sequences. These two primers permitted specific PCR amplification of a 288-bp DNA product from all 71 diverse $X$. albilineans strains tested. No amplification product was observed from any other bacterial species tested, including the three unidentified sugarcane saprophytes. The new PCR protocol has been routinely used to detect the leaf scald pathogen from infected sugarcane tissues.
\end{abstract}

Xanthomonas albilineans causes sugarcane leaf scald disease by colonizing the vascular system of leaves, stalks, and roots $(9,10)$. Although disease symptoms may appear at different stages of disease development, latent infections facilitate the increase and spread of the bacterial pathogen before it can be detected with conventional diagnostic methods based on symptoms, microscopy, and immunoassays (6). In order to detect the leaf scald pathogen with enhanced sensitivity, we developed a polymerase chain reaction (PCR) protocol (6) that utilized previously described PCR primers Ala4 (4) and L1 (5). The protocol amplified a unique DNA fragment of about $360 \mathrm{bp}$ from the $16 \mathrm{~S} / 23 \mathrm{~S}$ ribosomal DNA

Corresponding author: Y.-B. Pan

E-mail: ypan@nola.srrc.usda.gov

Product names and trademarks are mentioned to report factually on available data; however, the USDA neither guarantees nor warrants the standard of the product, and the use of the name by USDA does not imply the approval of the product to the exclusion of others that may also be suitable.

Accepted for publication 12 November 1998.

Publication no. D-1998-1211-01R

This article is in the public domain and not copyrightable. It may be freely reprinted with customary crediting of the source. The American Phytopathological Society, 1999. intergenic transcribed spacer (ITS) of a worldwide collection of $X$. albilineans strains, including representatives of the known serovars I, II, and III. In less than 6 $\mathrm{h}$ and at a material cost of less than $\$ 2$ per reaction, as little as $1.25 \mathrm{pg}$ of $X$. albilineans genomic DNA (125 fg if followed by Southern blot hybridization) or as few as five viable $X$. albilineans cells per reaction could be detected from a liquid culture, infected leaf diffusate, or vascular sap.

However, a potential problem was identified with this PCR protocol. Fragments of different sizes (about 280, 420, and $460 \mathrm{bp}$, respectively) were also amplified from three unidentified saprophytic bacteria (741, 22-19-6s, and CA-1) commonly found in sugarcane tissue $(6,7)$. This was due to the fact that primer $\mathrm{Ll}$ is a universal primer (5) and primer Ala4 (4) has limited specificity. To ensure correct identification of $X$. albilineans, modifications were made to the PCR protocol. First, a $2 \%$ agarose gel or a $0.7 \%$ agarose $/ 0.65 \%$ Synergel (Diversified Biotech, Boston, MA) binary gel was used to provide better separation of the PCR products. Second, the 360-bp PCR product from $X$. albilineans was run in both side lanes of the gel to serve as a standard and to help distinguish among these polymorphic PCR products. Further, it was sometimes necessary to run a mixture of the PCR sample in question with the 360-bp $X$. albilineans product in a single lane, or to conduct a Southern hybridization using the 360-bp X. albilineans product as a probe (6). A more specific, less complex protocol for the detection and identification of $X$. albilineans is needed. The objective of this study was to develop PCR primers highly specific to $X$. albilineans and to minimize identification problems.

\section{MATERIALS AND METHODS}

Bacterial strains. All bacterial strains used in a previous study (6) were included. These included $71 X$. albilineans strains, eight $X$. oryzae subsp. oryzae strains, two $X$. campestris strains, four $X$. campestris pv. translucens strains, three $X$. fragariae strains, seven unidentified bacterial saprophytes from sugarcane, and a Clavibacter xyli subsp. xyli strain. In addition, genomic DNA of seven $X$. campestris pv. vasculorum isolates, the causal bacterium of sugarcane gumming disease, from Asha Dookun (Mauritius Sugar Industry Research Institute, Rédit, Mauritius) were tested for primer specificity. These included race 1 isolates 3063, 3064, and 3065 , race 2 isolates 3359, 3043, and 3524, and race 3 isolate 2938 .

Amplification, cloning, and sequencing of PCR products. The PCR reaction mixture, thermal cycling program, agarose gel electrophoresis, radioactive labeling of probes, Southern hybridization, and gel purification of PCR products were according to Pan et al. (6). In addition, up to four batches of PCR samples amplified with the new primers developed in this study could be analyzed in a single agarose gel or agarose/Synergel binary gel containing $0.5 \mu \mathrm{g}$ of ethidium bromide per $\mathrm{ml}$. To do this, we ran the first batch of samples at 80 volts for $30 \mathrm{~min}$, viewed over UV transilluminator, recorded results, put the gel back to the electrophoresis unit, loaded the second batch of samples, and ran for another $30 \mathrm{~min}$ before recording the results for the second batch, and so on.

Ala4/L1-primed PCR amplification products from a local $X$. albilineans strain and the three unknown sugarcane bacterial saprophytes were gel purified and cloned into the pCR 2.1 vector using Original TA Cloning Kit (Invitrogen Corporation, Carlsbad, CA) following the manufacturer's recommendations. Plasmid DNA 
was extracted from 3-ml overnight TOP $10 F^{\prime}$ cultures by the alkali lysis method (12). DNA concentrations were determined on a GeneQuant II spectrophotometer (Pharmacia Biotech, Piscata- way, NJ). Recombinant clones were confirmed by EcoRI digestion to demonstrate the PCR product insert. Three clones per construct were sequenced on an automatic DNA Sequencer ABI200, Model 377
(Applied Biosystems, Foster City, CA) at the DNA Sequencing Facility, Iowa State University, Ames.

Computer-assisted DNA sequence analysis and primer design. Individual
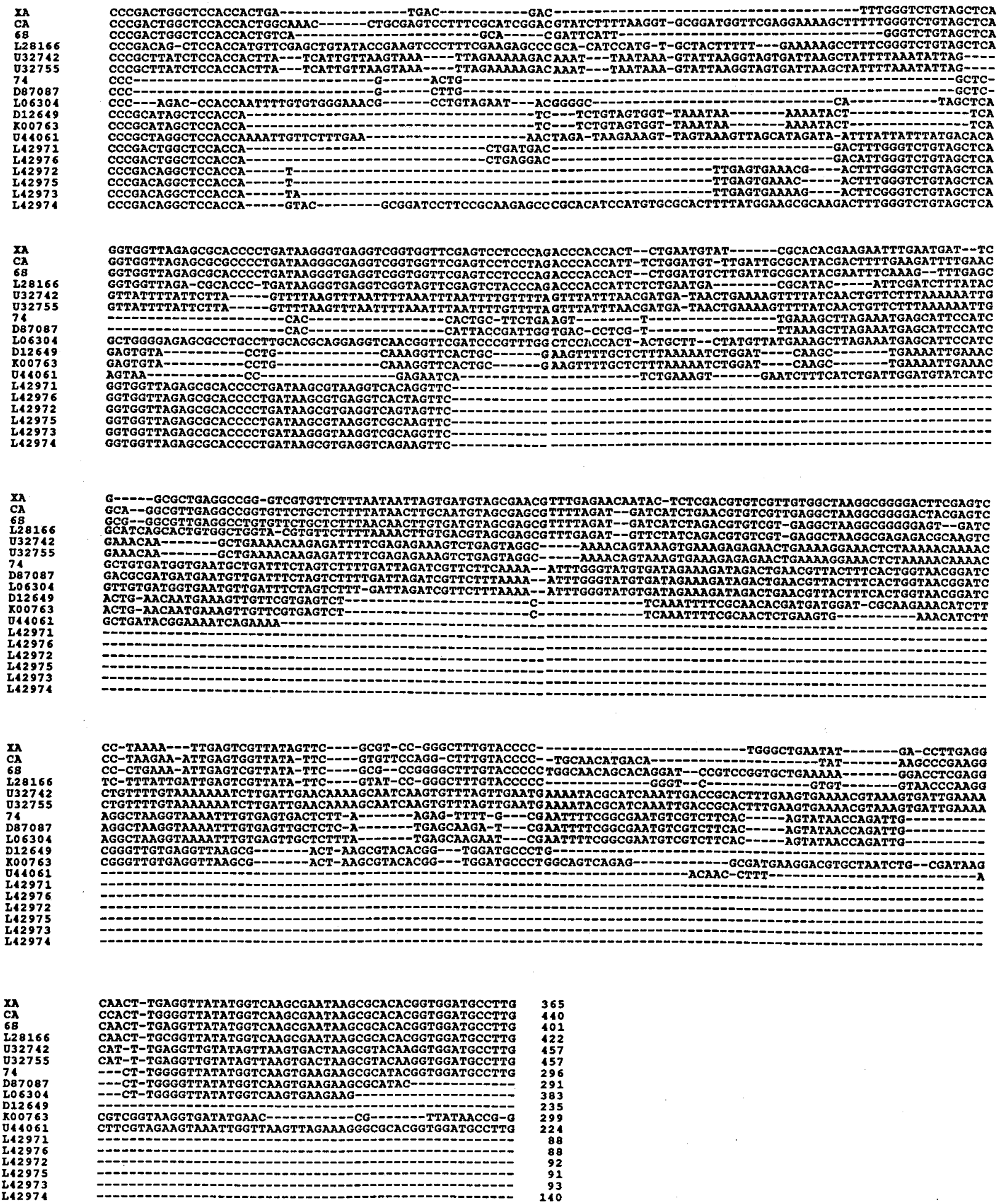

Fig. 1. A multiple sequence alignment among Xanthomonas albilineans (XA), three unidentified sugarcane saprophytic bacteria (74-1 [74], 22-19-6s [6S], CA1 [CA]), and 14 other bacterial species (GenBank Accession no. D12649, D87087, K00763, L06304, L28166, L42971, L42972, L42973, L42974, L42975, L42976, U32742, U32755, U44061) using PC/GENE Program (IntelliGenetics, Inc., Mountain View, CA) with the following parameters: K-tuple value $=2$; gap penalty $=5$; window size $=10$; filtering level $=2.5$; open gap cost $=10$; unit gap cost $=10$; and transitions are weighted twice as likely as transversions. 
DNA sequences were visually checked and edited against corresponding electropherograms to obtain a final sequence version for each bacterial species. The sequence from $X$. albilineans was used to search for its nonredundant, highly homologous sequences in the GenBank+EMBL+DDBJ+
PDB database using the BLASTN program of NCBI (1). A multiple sequence alignment was performed among these DNA sequences using the PC/GENE Clustal Program (IntelliGenetics, Inc., Mountain View, CA). Primer pairs were identified with the Primer Detective program

Table 1. Possible primer pairs for the 365-bp DNA sequence of Xanthomonas albilineans ${ }^{\mathrm{a}}$

\begin{tabular}{|c|c|c|}
\hline $\begin{array}{l}\text { Primer } \\
\text { pair no. }\end{array}$ & (Position) antisense primer $\left(5^{\prime}->3^{\prime}\right)$ & (Position) sense primer $\left(5^{\prime}->3^{\prime}\right)^{b}$ \\
\hline 1 & (14) ACC ACT GAT GAC GAC TTT GG & (243) CGA GTC CCT AAA ATT GAG TC \\
\hline 2 & (14) ACC ACT GAT GAC GAC TTT GG & (307) CCT TGA GGC AAC TTG AGG TT \\
\hline 3 & (23) GAC GAC TTT GGG TCT GTA GC & (243) CGA GTC CCT AAA ATT GAG TC \\
\hline 4 & (23) GAC GAC TTT GGG TCT GTA GC & (294) GGG CTG AAT ATG ACC TTG AG \\
\hline 5 & (23) GAC GAC TTT GGG TCT GTA GC & (307) CCT TGA GGC AAC TTG AGG TT \\
\hline 6 & (23) GAC GAC TTT GGG TCT GTA GC & (313) GGC AAC TTG AGG TTA TAT GG \\
\hline 7 & (28) CTT TGG GTC TGT AGC TCA GG & (243) CGA GTC CCT AAA ATT GAG TC \\
\hline $8^{c}$ & (28) CTT TGG GTC TGT AGC TCA GG & (296) GCT GAA TAT GAC CTT GAG GC \\
\hline 9 & (28) CTT TGG GTC TGT AGC TCA GG & (307) CCT TGA GGC AAC TTG AGG TT \\
\hline 10 & (103) CCA CCA CTC TGA ATG TAT CG & (307) CCT TGA GGC AAC TTG AGG TT \\
\hline 11 & (103) CCA CCA CTC TGA ATG TAT CG & (313) GGC AAC TTG AGG TTA TAT GG \\
\hline 12 & (109) CTC TGA ATG TAT CGC ACA CG & (307) CCT TGA GGC AAC TTG AGG TT \\
\hline 13 & (109) CTC TGA ATG TAT CGC ACA CG & (313) GGC AAC TTG AGG TTA TAT GG \\
\hline
\end{tabular}

a Parameters for primer search by Primer Detective (CLONETECH Laboratories Inc., CA) are 20mer for primer length, 150 to $350 \mathrm{bp}$ for target region length, 45 to $55 \%$ for primer GC content, 76 to $83.5^{\circ} \mathrm{C}$ melt temperature, and $3^{\prime}$ end homologies filtered.

${ }^{\mathrm{b}}$ Listed are the inverted complementary sequences of the sense primers.

${ }^{c}$ Contains antisense primer PGBL1 and the inverted complementary sequence of sense primer PGBL2.

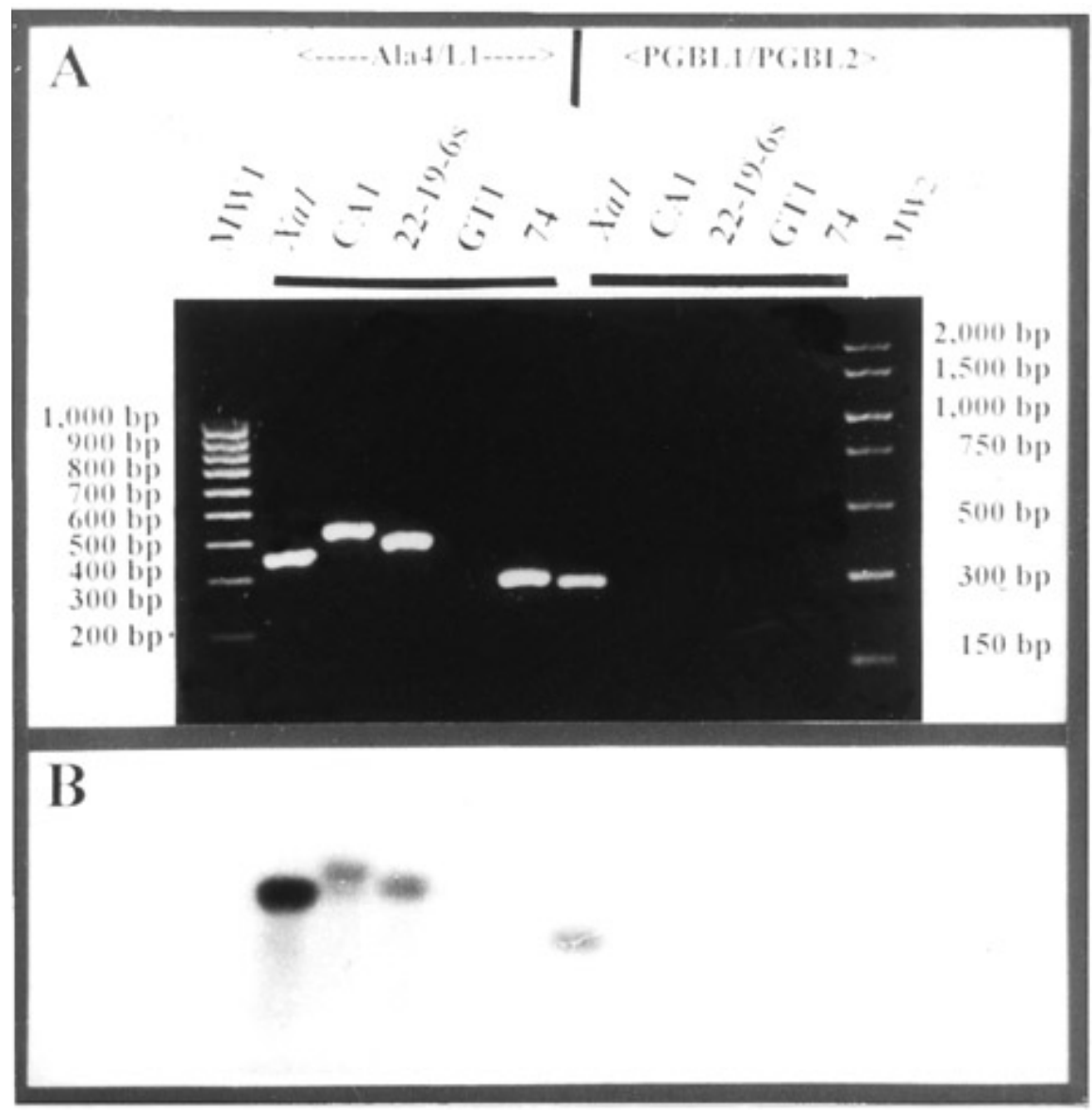

Fig. 2. (A) Ethidium bromide-stained polymerase chain reaction products following amplification either with primers Ala4/L1 or PGBL1/PGBL2 from Xanthomonas albilineans, CA1, 22-19-6s, GT1, and 74-1, as indicated at the top of each lane. DNA markers are in side lanes. (B) An autoradiograph of Southern blot of the gel shown in panel A with a ${ }^{32} \mathrm{P}-$ labeled Ala4/L1 fragment amplified from the genomic DNA of $X$. albilineans.

(CLONTECH Laboratories Inc., Palo Alto, $\mathrm{CA})$ using the following parameters: primer length (20-mer), target region length (150 to $350 \mathrm{bp}$ ), primer $\mathrm{GC} \%$ range (45 to $55 \%$ ), melt temperature ( 76 to $83.5^{\circ} \mathrm{C}$ ), and with $3^{\prime}$ end homologies filtered.

Specificity and sensitivity of PGBL1/ PGBL2-primed PCR protocol. The reaction mixture formula (except primer) and thermal cycling procedure were the same as described previously (6). The specificity of primers PGBL1 and PGBL2 was tested against all the bacterial strains, including the three unidentified sugarcane bacterial saprophytes (6) and the seven $X$. campestris pv. vasculorum isolates. Sensitivity tests were conducted on a 10-fold serial dilution of $X$. albilineans genomic DNA or suspension culture. The dilution series of the culture was titrated by a CFU assay on a semiselective medium $(2,3)$.

\section{RESULTS}

Cloning of Ala4/L1-primed PCR products. Ala4/L1-primed PCR products from $X$. albilineans, 74-1, 22-19-6s, and CA1, were successfully purified from an agarose/Synergel binary gel matrix, cloned into the pCR 2.1 plasmid vector, and transformed into competent $\mathrm{TOP} 10 \mathrm{~F}^{\prime}$ bacterial cells. Three recombinant plasmid clones were selected for each construct. EcoRIdigestion of these recombinant plasmids produced two expected DNA fragments: The larger fragments represented the pCR 2.1 plasmid vector and therefore were of the same size $(3.9 \mathrm{~kb})$. The smaller fragments represented various PCR product inserts with their corresponding sizes (not shown).

Computer-assisted DNA sequence analysis and primer design. Upon sequencing, the actual sizes of the Ala4/L1primed PCR products from $X$. albilineans, 74-1, 22-19-6s, and CA1, were 365, 296, 401, and 439 bp, respectively (Fig. 1). Fourteen nonredundant sequences (GenBank Accession No. D12649, D87087, K00763， L06304, L28166, L42971, L42972， L42973， L42974， L42975, L42976, U32742, U32755, U44061) that were highly homologous to the $X$. albilineans sequence were retrieved from the GenBank database. An alignment among these 18 DNA sequences is shown in Figure 1.

Selection of $X$. albilineans-specific PCR primers. A total of 13 pairs of PCR primers was found (Table 1). Primers PGBL1 (5' CTT TGG GTC TGT AGC TCA GG from positions 28 to 47) and PGBL2 (5' GCC TCA AGG TCA TAT TCA GC, an inverted complementary sequence of 5' GCT GAA TAT GAC CTT GAG GC from positions 296 to 315 in $X$. albilineans sequence) were chosen because they shared the least homology with all other related sequences and gave a relatively large product of $288 \mathrm{bp}$.

Specificity of PGBL1 and PGBL2. As expected, PGBL1/PGBL2 primed specific 
amplification of a 288-bp DNA product from a locally isolated $X$. albilineans strain, $X a 1$. In contrast, no amplification products were observed for unidentified sugarcane bacterial saprophytes 74-1, 2219-6s, CA1, and GT1 (Fig. 2A). This was confirmed by Southern hybridization with a ${ }^{32}$ P-labeled 365-bp Ala4/L1-primed DNA probe derived from $X$. albilineans (Fig. 2B). These two primers also amplified the 288-bp product from all 70 other $X$. albilineans strains, including representative strains of serovars I (CP5, G44, and R8), II (c1-35 and HV5), and III (G7, STK3), and from $X$. albilineans-infected field-grown sugarcane leaf diffusate or sap samples. For example, in one test, 61 out of the 71 sap samples tested positive and produced the 288-bp PCR product (Fig. 3). No amplification product was observed from $X$. oryzae, X. campestris, X. fragariae, any isolated sugarcane bacterial saprophyte, or the seven $X$. campestris pv. vasculorum isolates (data not shown).

Sensitivity of PGBL1/PGBL2-primed PCR protocol. The protocol detected as little as $1 \mathrm{pg}$ (ethidium bromide staining) or $10 \mathrm{fg}$ (blotted and hybridized with a ${ }^{32} \mathrm{P}$ labeled Ala4/L1-primed PCR product from $X$. albilineans) of $X$. albilineans genomic DNA and as few as four $X$. albilineans cells per reaction.

\section{DISCUSSION}

New PCR primers PGBL1 and PGBL2 were developed in this study for specific detection of $X$. albilineans. This pair of primers was chosen out of the 13 possible primer pairs (Table 1), mainly because they shared the least homology with all the other related sequences (Fig. 1). As such, we have greatly improved the specificity of our earlier PCR protocol (6). Under the same PCR conditions (reaction mixture formula, thermal cycling program, and thermal cycler), PGBL1 and PGBL2 primed amplification of an expected DNA product of $288 \mathrm{bp}$ from the genomic DNA of 71 diverse $X$. albilineans strains that included representatives of the three known serovars $(10,11)$. In contrast, amplification products were not observed among any other bacterial strains, including the seven isolates of $X$. campestris pv. vasculorum, the causal bacterium of sugarcane gumming disease. This greatly improved specificity will prevent possible misinterpretation of results by eliminating nonspecific amplification. Use of the improved PCR protocol will be more effective for quarantine as well as for routine diagnosis of $X$. albilineans infection. For example, control measures such as more highly concentrated agarose gels and standard $X$. albilineans PCR product in side lanes were no longer needed.

It is possible that other bacterial species might amplify a DNA product with the new PCR protocol; however, this is very unlikely because the new primers PGBL1 and PGBL2 were designed on the basis of a multiple sequence alignment among se- quences of $X$. albilineans, the three unidentified bacterial saprophytes, and 14 other highly homologous sequences from the database (Fig. 1). Since the development of the new PCR protocol, we have assayed several hundred sugarcane leaf diffusate or sap samples and not encountered a case where a PCR product other than 288 bp in size was amplified (unpublished). In a recent study on the distribution of $X$. albilineans among internodes of infected sugarcane stalks (8), we often encountered at least one bacterial species that produced colonies on a semiselective medium (2) that were morphologically similar to those of $X$. albilineans. However, no DNA product was amplified from the colonies of the species using the PGBL1 and PGBL2 primers. Serological tests of these colonies with monoclonal anti- $X$. albilineans antibodies also showed negative results (data not shown).

The detection limit of the new PCR protocol was about $1 \mathrm{pg}$ of $X$. albilineans genomic DNA or about $4 \mathrm{CFU}$ of cultured $X$. albilineans cells per reaction based on ethidium bromide-stained gel analysis. This was comparable to Ala4/L1-primed PCR protocol (6) and was probably due to the fact that both sets of primers are within the ITS region and that assays were conducted under identical PCR conditions. We did not compare the detection limit on infected sugarcane tissue but assumed that the new PCR protocol should work equally

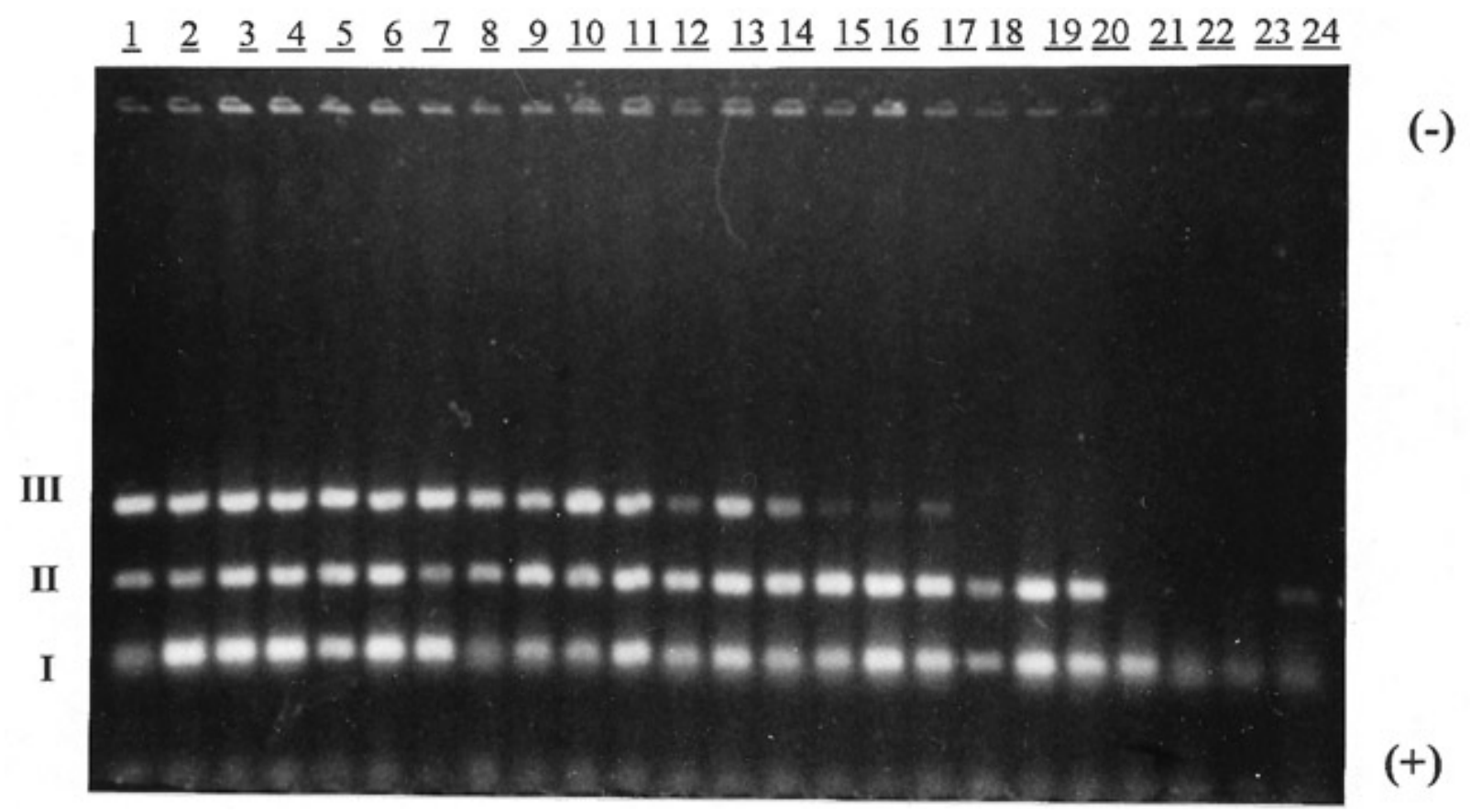

Fig. 3. Ethidium bromide-stained polymerase chain reaction (PCR) products following amplification with primers PGBL1/PGBL2 from sugarcane vascular sap samples. Three batches, I, II, and III, of 24 PCR samples $(10 \mu$ 1/lane) each were loaded into the same gel, with an interval of 30 min at 80 volts between consecutive loadings. Presence of the 288-bp Xanthomonas albilineans-specific fragment was recorded prior to the next loading for two reasons. One was that the primer dimers from one loading (for example, batch III) could comigrate with the PCR products of previous loadings (for example, batch I, of which negative control sample was loaded in lane 24. The apparent faint images along the PCR product line in lanes 1, 8, 22, 23, and 24 were primer dimers from batch III). The second reason was that the dye, ethidium bromide, carries a positive charge and migrates toward the cathode; as a result, DNA products may lose their fluorescence during the entire electrophoretic course, particularly those samples with a lower yield (for example, those in lanes 12 , 15,16 , and 17 from batch III, and the one in lane 24 from batch II). 
well on sap and leaf diffusate samples. However, data obtained from recent experiments indicated that the detection limit on sugarcane sap could be improved by using more Taq DNA polymerase, from 0.625 units to 2.5 units per reaction, by extending both denaturation and annealing steps from $1 \mathrm{~s}$ to $10 \mathrm{~s}$, and by increasing the total number of cycles from 30 to 40 (unpublished). We believe that this PCR protocol can provide sugarcane industries worldwide with a highly specific molecular tool for the detection of the leaf scald pathogen, thereby aiding in its control.

\section{ACKNOWLEDGMENTS}

We thank C. A. Clark (LSU, Baton Rouge, LA) for various $X$. albilineans and non- $X$. albilineans strains, and J. C. Comstock (USDA-ARS, Canal Point, FL), A. Dookun (Mauritius Sugar Industry Research Institute, Réduít, Mauritius), N. W. Schaad (USDA-ARS-FDWSR, Fort Detrick, MD), and S. Schenck (Hawaii Agriculture Research Center, Aiea, HI) for genomic DNA of various $X$. albilineans strains. We also thank J. E. Leach (KSU, Manhattan, KS) for genomic DNA of five Xoo strains; A. Dookun for genomic DNA of seven $\mathrm{Xcv}$ isolates; Jeffrey W. Cary, Kenneth C.
Ehrlich, and Barbara A. Triplett (USDA-ARS, Southern Regional Research Center, New Orleans, LA) for DNA sequence analysis; and Kathryn Z. Warnke for technical assistance. This research was partially supported by a competitive grant from the American Sugar Cane League of the USA, Inc., Thibodaux, LA.

\section{LITERATURE CITED}

1. Altschul, S. F., Gish, W., Miller, W. Myers, E. W., and Lipman, D. J. 1990. Basic local alignment tool. J. Mol. Biol. 215:403-410.

2. Davis, M. J., Rott, P., Baudin, P., and Dean, J. L. 1994. Evaluation of selective media and immunoassays for detection of Xanthomonas albilineans, causal agent of sugarcane leaf scald disease. Plant Dis. 78:78-82.

3. Davis, M. J., Rott, P., and Dean, J. L. 1994. Selective isolation of Xanthomonas albilineans, causal agent of leaf scald disease. Proc. Int. Soc. Sugar Cane Technol. 21:476-484.

4. Honeycutt, R. J., Sobral, B. W. S., and McClelland, M. 1995. tRNA intergenic spacers reveal polymorphisms diagnostic of Xanthomonas albilineans. Microbiology 141:3229-3239.

5. Jensen, M. A., Webster, J. A., and Straus, N. 1993. Rapid identification of bacteria on the basis of polymerase chain reaction-amplified ribosomal DNA spacer polymorphisms. Appl.
Environ. Microbiol. 59:945-952.

6. Pan, Y.-B., Grisham, M. P., and Burner, D. M 1997. A polymerase chain reaction protocol for the detection of Xanthomonas albilineans, the causal agent of sugarcane leaf scald disease. Plant Dis. 81:189-194.

7. Pan, Y.-B., Grisham, M. P., Burner, D. M., and Legendre, B. L. 1998. Detecting sugarcane disease pathogens by DNA-based technology. 1996 Proc. Inter-Am. Sugar Cane Seminars Vol. I:224-237.

8. Pan, Y.-B., Grisham, M. P., Burner, D. M., and Wei, Q. Distribution of the leaf scald pathogen in infected sugarcane stalks. J. Am. Soc. Sugar Cane Technol. In press.

9. Ricaud, C., and Ryan, C. C. 1989. Leaf scald. Pages 39-58 in: Diseases of Sugarcane. C. Ricaud, B. T. Egan, A. G. Gillispie, Jr., and C. G. Hughes, eds. Elsevier, Amsterdam.

10. Rott, P., Arnaud, M., and Baudin, P. 1986. Serological and lysotypical variability of Xanthomonas albilineans (Ashby) Dowson, casual agent of sugarcane leaf scald disease. J. Phytopathol. 116:201-211.

11. Rott, P., Davis, M., and Baudin, P. 1994 Serological variability in Xanthomonas albilineans, causal agent of leaf scald disease of sugarcane. Plant Pathol. 43:344-349.

12. Sambrook, J., Fritsch, E. F., and Maniatis, T. A. 1989. Molecular Cloning: A Laboratory Manual. 2nd ed. Cold Spring Harbor Laboratory, Cold Spring Harbor, NY. 